Tragicomic Redemptions 
This page intentionally left blank 


\title{
Tragicomic Redemptions
}

Global Economics and the Early

Modern English Stage

\author{
VALERIE FORMAN
}

\section{$\overline{\text { PENN }}$}

University of Pennsylvania Press

Philadelphia 
Copyright (C) 2008 University of Pennsylvania Press

All rights reserved. Except for brief quotations used for purposes of review or scholarly citation, none of this book may be reproduced in any form by any means without written permission from the publisher.

Published by

University of Pennsylvania Press

Philadelphia, Pennsylvania 19104-4112

Printed in the United States of America on acid-free paper

$\begin{array}{llllllllll}10 & 9 & 8 & 7 & 6 & 5 & 4 & 3 & 2 & 1\end{array}$

Excerpt from Patti Smith, "In Excelsis Deo." Written by Patti Smith $\odot 1975$ Linda Music. Used by Permission. All Rights Reserved.

\section{Library of Congress Cataloging-in-Publication Data}

Forman, Valerie.

Tragicomic redemptions : global economics and the early modern English stage / Valerie Forman.

p. cm.

Includes bibliographical references and index. ISBN: 978-0-8122-4096-2 (acid-free paper)

1. English drama-Early modern and Elizabethan, 1500-1600-History and criticism. 2. Economics in literature. 3. Literature and globalization. 4. Literature and societyEngland. 5. Drama-Economic aspects-England. 6. Theater-Economic aspects-England.

7. Theater-England-History-16th century. 8. Theater-England-History-17th century. PR658.E35 F67 2008

$822.3^{\prime} 09355322$

2008004163 
In memory of Leonard Forman, who directed the first plays I ever saw 
This page intentionally left blank 